\title{
IDENTIFIKASI BAKTERI PADA PEGANGAN ESKALATOR DI SALAH SATU PUSAT PERBELANJAAN DI KOTA MANADO
}

\author{
Michelle V. Holderman ${ }^{1)}$, Edwin de Queljoe ${ }^{1)}$, Sendy B. Rondonuwu ${ }^{1)}$ \\ ${ }^{1)}$ Program Studi Biologi, FMIPA Universitas Sam Ratulangi Manado \\ vivianychelle@gmail.com; edwin_de_queljoe@yahoo.co.id; rondonuwu64@yahoo.com;
}

\begin{abstract}
ABSTRAK
Pusat perbelanjaan banyak diminati masyarakat karena mempunyai daya tarik internal dan eksternal. Eskalator pada pusat perbelanjaan dilengkapi dengan pegangan tangan, dengan demikian eskalator dapat menjadi media untuk penjangkitan penyakit yang dapat dengan cepat menyebar karena bakteri pada tangan dapat berpindah ke tangan orang lain apabila memegang pegangan dari eskalator tersebut. Tujuan penelitian ini yaitu untuk mengidentifikasi jenis-jenis bakteri yang terdapat pada pegangan escalator. Metode yang digunakan dalam penelitian ini yaitu identifikasi bakteri meliputi pengamatan morfologi dan pewarnaan gram. Berdasarkan hasil penelitian jenis bakteri yang ditemukan yaitu Staphylococcus epidermidis, Stomatococcus sp, Bacillus subtilis.
\end{abstract}

Kata-kata kunci: Pusat perbelanjaan, eskalator, bakteri

\section{IDENTIFICATION OF BACTERIA IN HANDRAIL ESCALATOR ON SHOPPING CENTER IN MANADO}

\begin{abstract}
Shopping center attracted many people because they have internal and external appeal. Escalators in shopping center equipped with handrails, thus escalator can be a medium for the outbreak of disease can quickly spread because bacteria on the hands can be transferred into other hands when holding the handle of the escalator that. The purpose of this study is to identify the types of bacteria present on escalator handrail. The method used in this research is the identification of bacteria includes observation of morphology and gram stain. Based on the results of the study found that the type of bacteria Staphylococcus epidermidis, Stomatococcus sp, Bacillus subtilis.
\end{abstract}

Kata-kata kunci: Shopping center, escalator, bacteria

\section{PENDAHULUAN}

Masyarakat perkotaan pada umumnya memiliki aktivitas dan rutinitas pekerjaan sehari-hari yang padat sehingga membutuhkan tempat rekreasi untuk memulihkan kesegaran dan kesehatan tubuh (Marpaung, 2000).

Salah satu tujuan tempat rekreasi bagi masyarakat perkotaan yaitu pusat perbelanjaan. Pusat perbelanjaan pada awalnya adalah suatu tempat yang berfungsi sebagai tempat perdagangan atau tempat bertemunya penjual dan pembeli dalam melakukan transaksi namun sejalan dengan kemajuan dibidang teknologi, pusat perbelanjaan telah berkembang dari fungsi asalnya sebagai pusat konsumsi atau perdagangan kini beralih menjadi tempat tujuan rekreasi yang menarik, menyenangkan, dan nyaman; tempat untuk mendapatkan hiburan, berinteraksi sosial bersama teman dan keluarga; maupun menjadi tempat untuk berbisnis bahkan menjadi gaya hidup (Neo dan Wing, 2005).

Kota Manado merupakan ibukota Provinsi Sulawesi Utara yang terletak di ujung pulau dan menjadi kota terbesar di Sulawesi Utara dengan jumlah penduduk yaitu 425.634 jiwa (Badan Pusat Statistik, 2015) di Kota Manado terdapat beberapa pusat perbelanjaan, diantaranya yaitu Manado Town Square yang terletak di pinggir pantai 
(Sompie dan Kristanto, 2013). Manado Town Square banyak diminati masyarakat dibandingkan dengan pusat perbelanjaan yang lain karena mempunyai daya tarik internal yaitu memiliki fasilitas perbelanjaan dan rekreasi yang lengkap, memiliki daya tarik eksternal yaitu aksesibilitas yang baik dengan jarak yang mudah dicapai dari berbagai penjuru, tidak terlalu memakan waktu yang lama ketika melakukan perjalanan ke pusat perbelanjaan ini serta tersedianya tempat parkir teratur yang disediakan dekat dengan setiap pintu masuk (Gogugu et al., 2015).

Pusat perbelanjaan kini telah berkembang menjadi tempat umum yang banyak dikunjungi mayarakat dari berbagai kalangan. Sejumlah penelitian telah menunjukkan bahwa permukaan umum yang di gunakan seperti computer, telepon headset, gagang pintu, kereta belanja, dan Automatic Teller Macine (ATM) merupakan sumber potensial dari infeksi bakteri dan virus yang menyebabkan penyebaran flu, pilek, dan diare (Ashgar, dan El-Said, 2012).

Pada pusat perbelanjaan terdapat permukaan umum yang menjadi salah satu fasilitas yang disediakan pusat perbelanjaan untuk membantu pengunjung yaitu eskalator. Eskalator merupakan tangga dengan anakanak tangga yang terus bergerak naik atau turun dan diperlengkapi dengan pegangan yang dapat digunakan untuk membantu menjaga keseimbangan pada saat menaiki eskalator yang terus bergerak (Kamus Online Bahasa Indonesia, 2016).

Penelitian mengenai potensi patogen bakteri yang terdapat di tempat umum sebelumnya telah dilakukan di bagian timur Saudi Arabia yaitu di pusat Kota Dammam, Khobar, dan Qatif yaitu pada pegangan tangan eskalator, kereta belanja dan Automated Teller Machine (ATM). Hasil penelitian menunjukan bahwa bakteri yang paling banyak ditemukan yaitu pada pegangan eskalator dan mesin ATM dengan bakteri yang paling umum ditemukan adalah Bacillus subtilis, Micrococcus luteus, Bacillus cereus, Kocuria atrina dan Staphylococcus epidermidis yang dapat menyebabkan infeksi kulit, infeksi saluran kemih, meningitis, endocarditis, infeksi mata dan lainnya (Aldosary, 2016).

Menurut Radji (2011) salah satu penyebab penyakit infeksi disebabkan oleh bakteri. Bakteri merupakan salah satu golongan mikroorganisme prokariotik (bersel tunggal) yang hidup berkoloni dan tidak mempunyai selubung inti namun mampu hidup dimana saja (Jawetz et al., 2004). Menurut klasifikasinya bakteri dibagi menjadi 2 yaitu bakteri Gram positif dan bakteri Gram negatif. Beberapa bakteri Gram positif dan bakteri Gram negatif merupakan flora normal pada tubuh manusia. Flora normal adalah mikroorganisme yang menempati suatu daerah tanpa menimbulkan penyakit pada inang yang ditempati. Pada kulit normal biasanya ditempati sekitar $10^{2}$ $10^{6} \mathrm{CFU} / \mathrm{cm}^{2}$ bakteri (Trampuz dan Widmer, 2004). Ada juga sebagian dari bakteri Gram positif dan bakteri Gram negatif misalnya Staphylococcus aereus yang dapat menyebakan penyakit jika mencapai jumlah 1.000 .000 atau $10^{6}$ per Gram yang merupakan suatu jumlah yang cukup untuk memproduksi toksin (Synder, 1988).

\section{Pusat Perbelanjaan}

Kegiatan berbelanja merupakan kegiatan manusia untuk memenuhi kebutuhan hidup dan hampir setiap manusia dalam masyarakat melakukannya. Berbagai fasilitas disediakan untuk memenuhi kebutuhan berbelanja manusia mulai dari pasar tradisional hingga pusat perbelanjaan modern yang kini banyak diminati masyarakat diantaranya yaitu mall (Schiffman dan Kanuk, 2004).

\section{Eskalator}

Eskalator adalah salah satu transportasi vertikal berupa konveyor untuk mengangkut orang, yang terdiri dari tangga terpisah yang dapat bergerak ke atas dan kebawah mengikuti jalur berupa rantai rail atau rantai yang digerakkan oleh motor. Eskalator dilengkapi dengan pegangan tangan. Pegangan tangan terbuat dari bahan karet khusus dengan lapisan baja penguat yang berfungsi untuk mencegah penumpang jatuh pada saat masuk atau keluar dari anak tangga (Syah, 2007)

\section{Bakteri}

Bakteri merupakan salah satu golongan organisme prokariotik (tidak mempunyai selubung inti) namun bakteri memiliki informasi genetik berupa DNA yang berbentuk sirkuler, panjang dan bisa disebut 
nucleoid. Tes bokimia pewarnaan gram merupakan kriteria yang efektif untuk klasifikasi. Hasil pewarnaan akan menunjukkan perbedaan dasar dan kompleks pada sel bakteri (struktur dinding sel), sehingga dapat membagi bakteri menjadi 2 kelompok yaitu bakteri Gram positif dan bakteri Gram negatif (Jawetz et al., 2004). Pada pewarnaan Gram, golongan bakteri gram positif akan memberikan warna ungu karena memiliki lapisan peptidoglikan setebal 20-80nm sedangkan Bakteri Gram negatif memiliki lapisan peptidoglikan yang tipis yaitu 5-10 $\mathrm{nm}$ dengan komposisi utama: lipoprotein, membran luar dan polisakarida.

\section{METODE PENELITIAN}

Penelitian ini dilakukan selama bulan Agustus sampai bulan Oktober 2016. Pembuatan media dan kultur bakteri dilakukan di Laboratorium Mikrobiologi FMIPA UNSRAT, Pengambilan sampel bakteri dilakukan di salah satu pusat perbelanjaan yang ada di Manado (3 lokasi pengambilan) dan Identifikasi bakteri dilakukan di Dinas Kesehatan Provinsi Sulawesi Utara.

Alat yang digunakan yaitu cottonbud berukuran besar, inkubator, autoclave, timbangan analitik, alumunium foil, plastik obat, kapas, kasa, gelas piala, magnet stirer bar, hotplate, tabung reaksi, eppendorf, pipet, jarum inokulasi, tabung kecil, petri dish, hand sanitaizer, plastik pembungkus dan alat tulis menulis. Bahan yang digunakan berupa nutrient agar, air steril (millique water), kristal violet, lugol, alkohol 95\%, safranin, dan media Mannitol Salt Agar.

Ditimbang bubuk nutrient agar sebanyak 14 gram dan dimasukkan kedalam $500 \mathrm{ml}$ air kemudian dididihkan diatas hot plate dengan suhu $260^{\circ} \mathrm{C}$ selama kurang lebih 20 menit. Nutrient agar yang telah mendidih dituang kedalam petri dish sebanyak $20 \mathrm{ml}$ dan pada tabung reaksi sebanyak $5 \mathrm{ml}$ lalu diberi tutup menggunakan kapas dan kasa. Alat dan bahan yang digunakan disterilisasi menggunakan autoklaf. Pengambilan sampel dilakukan dengan cara cottonbud dicelupkan kedalam tabung kecil berisi $5 \mathrm{ml}$ air steril kemudian air tersebut disebarkan pada media tanam bakteri dan diinkubasi selama 48 jam. Identifikasi bakteri dilakukan dengan cara mengamati morfologi koloni meliputi bentuk koloni bakteri, warna koloni, tepi koloni, dan elevasi koloni bakteri (Nurhari 2009). Kemudian dilanjutkan dengan pewarnaan Gram yang bertujuan untuk mengetahui golongan bakteri jika bakteri Gram positif akan berwarna ungu dan jika bateri Gram negatif akan berwarna agak merah (Willey et al., 2008). Pewarnaan Gram dilakukan dengan cara bakteri difiksasi diatas microscope slides menggunakan $\mathrm{NaCl}$ dan yang pertama diberi larutan kristal violet selama 3 menit, lugol selama 1 menit, alkohol 95\% selama 30 detik dan safranin selama 2 menit.

\section{HASIL DAN PEMBAHASAN}

Hasil yang didapatkan pada pengamatan morfologi koloni yaitu seperti dalam Tabel 1.

Pada hasil pengamatan morfologi koloni bakteri, didapatkan koloni bakteri berbentuk bulat dengan tepi utuh yang mendominasi namun ada juga beberapa koloni bakteri dengan tepi bergerigi, warna beragam yaitu putih, kuning, dan merah serta elevansi tumbuh dipermukaan. Morfologi koloni bakteri perlu diamati untuk mempermudah dalam proses identifikasi bakteri karena sifatsifat koloni bakteri dapat menentukan jenis bakteri tersebut.

Koloni sel bakteri merupakan sekelompok sel yang dapat dilihat secara langsung dengan mata. Koloni bakteri dapat berbentuk bulat, tak beraturan dengan permukaan cembung, cekung atau datar serta tepi koloni rata atau bergelombang (Cappucino, 1987).

Berdasarkan hasil penelitian Wahyuni (2011) menyatakan dengan melakukan pengamatan morfologi bakteri akan memudahkan dalam mengidentifikasi bakteri misalnya bakteri Bacillus sp. koloni muncul di atas permukaan media Nutrient Agar (NA) dengan warna koloni kuning, krem atau putih kusam, dan merah kecoklatan, bakteri Staphylococcus sp. koloni muncul di atas permukaan media NA dengan koloni berwarna putih dan permukaan koloni mengkilat. 
Tabel 1. Bentuk dan morfologi koloni berdasarkan isolat

\begin{tabular}{|c|l|}
\hline Isolat & \multicolumn{1}{|c|}{ Bentuk dan Morfologi Koloni Bakteri } \\
\hline A & Bentuk : Bulat, Warna : Putih, Tepi : Utuh, Elevasi: Tumbuh dipermukaan \\
\hline B & $\begin{array}{l}\text { Bentuk : Bulat tidak teratur, Warna : Putih agak transparan, Tepi : Bergerigi, Elevasi } \\
\text { : Rata }\end{array}$ \\
\hline C & $\begin{array}{l}\text { Bentuk : Bulat kecil (seperti titik-titik), Warna : Kuning, Tepi : Utuh,, Elevasi: } \\
\text { Tumbuh di permukaan }\end{array}$ \\
\hline D & $\begin{array}{l}\text { Bentuk : Bulat lengket, Warna : Putih keruh, Tepi : bergelombang, Elevasi : Tumbuh } \\
\text { di permukaan }\end{array}$ \\
\hline E & $\begin{array}{l}\text { Bentuk : Bulat licin, Warna : Putih keruh, Tepi : Utuh, Elevasi : Tumbuh di } \\
\text { permukaan rata }\end{array}$ \\
\hline F & $\begin{array}{l}\text { Bentuk : Bulat, Warna : Merah, Tepi : Utuh, Elevasi : Tumbuh di permukaan } \\
\text { cembung }\end{array}$ \\
\hline G & $\begin{array}{l}\text { Bentuk : Bulat licin, Warna : Putih Keruh, Tepi : Utuh, Elevasi : Tumbuh di } \\
\text { permukaan }\end{array}$ \\
\hline H & Bentuk : Bulat, Warna : Putih Bening, Tepi : Utuh, Elevasi : Tumbuh di permukaan \\
\hline I & $\begin{array}{l}\text { Bentuk : Seperti akar Berlendir, Warna : Putih, Tepi : Bergerigi, Elevasi : Tumbuh di } \\
\text { permukaan cembung }\end{array}$ \\
\hline J & Warna : Kuning, Tepi : Utuh, Elevasi : Tumbuh di permukaan datar \\
\hline
\end{tabular}

Setelah pengamatan morfologi koloni bakteri dilakukan pewarnaan Gram. Berdasarkan hasil pengamatan diketahui bahwa isolat $\mathrm{A}, \mathrm{C}$, dan $\mathrm{D}$ merupakan bakteri Gram positif coccus, isolat $\mathrm{B}, \mathrm{E}, \mathrm{F}, \mathrm{G}, \mathrm{H}, \mathrm{I}, \mathrm{J}$ merupakan bakteri Gram positif basil.

Isolat $\mathrm{A}, \mathrm{C}$ dan $\mathrm{D}$ merupakan bakteri Gram positif coccus karena pada saat pewarnaan Gram bakteri-bakteri ini berwarna ungu dan berbentuk bulat. Untuk mengetahui jenis dari bakteri Gram positif coccus ini dilakukan pengujian pada media Mannitol Salt Agar (MSA). Pengujian ini bertujuan untuk mengetahui kemampuan bakteri dalam memfermentasi mannitol. Apabila bakteri tersebut dapat memfermentasi mannitol maka media akan berubah warna dari merah menjadi kuning. Pada pengujian ini isolat $\mathrm{A}$ dan $\mathrm{C}$ tidak menunjukan perubahan warna, hal tersebut menunjukkan bakteri tidak memfermentasi mannitol yang berarti isolat ini merupakan bakteri Staphylococcus epidermidis.

Media MSA merupakan media yang mengandung garam natrium klorida 7,5\% dan indikator $\mathrm{pH}$ phenol red sehingga media ini menjadi media selektif karena sebagian besar bakteri tidak dapat tumbuh pada konsenterasi garam 7,5\% kecuali jenis bakteri Staphylococcus. Jenis bakteri Staphylococcus aureus akan menghasilkan koloni kuning dengan zona kuning karena bakteri tersebut dapat memfermentasi manitol menjadi asam yang kemudian merubah warna indikator phenol red dari merah menjadi kuning, sedangkan Staphylococcus epidermidis menghasilkan koloni merah muda kecil atau merah dengan tidak ada perubahan warna medium karena tidak memfermentasi manitol.

Pada pewarnaan Gram sampel D menunjukan warna ungu yang berarti bakteri ini merupakan bakteri Gram positif dan pada saat pengamatan dibawah mikroskop bakteri ini berbentuk bulat namun lebih besar dari pada bakteri Staphylococcus. Berdasarkan hal tersebut disimpulkan bahwa bakteri tersebut termasuk pada kelompok bakteri Stomatococcus. Menurut Fanourgiakis (2003), genus Stomatococcus merupakan bakteri yang sulit dibedakan dengan genus Micrococcus dan Staphylococcus namun dapat dibedakan melalui bentuk koloninya.

Pada isolat B, E, F, G, H, I, J berwarna merah yang berarti merupakan 
bakteri Gram negatif namun pada saat diamati dibawah mikroskop bakteribakteri tersebut terlalu menumpuk dan bentuk selnya berbeda dari bakteri Gram negatif pada umumnya. Untuk memastikan kembali apakah bakteri tersebut adalah Gram negatif dilakukan penanaman bakteri pada media MacConkey (MCA).

Media MCA merupakan media yang memiliki senyawa utama yaitu laktosa, garam empedu, dan merah netral sebagai indikator warna. MCA merupakan medium kultur yang dirancang untuk menumbuhkan bakteri Gram-negatif dan membedakan mereka berdasarkan kemampuan memfermentasi laktosa. Media ini berisi garam empedu untuk menghambat sebagian besar bakteri Gram-positif dengan adanya garam empedu yang akan membentuk kristal violet, serta pewarna merah netral sebagai $\mathrm{pH}$ indikator untuk mengetahui adanya fermentasi laktosa (Lay, 1994). Menurut Compant et al (2005), genus Bacillus biasanya digunakan sebagai agen biokontrol secara luas, bakteri ini mampu menghasilkan zat antimikroba berupa bakteriosin. Bakteriosin adalah zat antimikroba polipeptida atau protein yang diproduksi oleh mikroorganisme yang bersifat bakterisida. Bakteriosin membunuh sel targetnya dengan menyisip pada membran target dan mengakibatkan fungsi membran sel menjadi tidak stabil sehingga menyebabkan sel lisis.

Tiga jenis bakteri tersebut ditemukan pada pegangan eskalator karena adanya kontak langung antara tangan dengan pegangan eskalator maupun penyebaran melalui udara. Kondisi pusat perbelanjaan yang ramai memungkinkan banyak kontak langsung dengan pegangan eskalator. Diduga pengguna eskalator yang tanpa sadar menutup mulut ketika menguap, berbicara mengeluarkan salifa, bersin, luka, ataupun jari anak-anak yang dimasukan kedalam mulut dan kemudian kontak dengan pegangan eskalator menjadi media penyebaran bakteri ini.

Menurut Wattimena et al (1991), penyebaran dan penularan penyakit infeksi pada manusia pada dasarnya terjadi melalui tiga cara, inhalasi, ingesti, dan melalui vektor hewan atau manusia lain. Cara penularan inhalasi melalui sistem respirasi, cara penularan ingesti melalui makanan atau minuman yang dimakan, dan cara penularan melalui vektor hewan atau manusia lain yaitu melalui vektor atau perantara berupa hewan atau manusia sebagai karier sebelum menjalar ke manusia lain dan menimbulkan penyakit .

S.epidermidis merupakan flora normal pada kulit, membran mukosa manusia, rongga hidung bagian depan, dan saluran pencernaan. Bakteri ini juga sering ditemukan pada selaput lendir, bisul dan luka (Jawetz et al., 2010). Berbeda halnya dengan bakteri Stomatococcus yang ditemukan di eskalator ini diduga Stomatococcus mucilaginous karena bakteri merupakan flora normal pada bagian orofaringeal (Fanourgiakis, 2003) dan untuk pertama kali bakteri ini diisolasi dari selaput lender pipi dan gusi manusia (Hermann et al., 1995). Selanjunya yaitu bakteri Bacillus subtilis, karna pemindahan ketujuh isolat bakteri yang telah dilakukan berulang kali maka bakteri ini dapat dengan mudah mengkontaminasi ke tujuh isolat. Sifat bakteri ini sebagai agen biokontrol secara luas yaitu mempunyai kemampuan untuk menghasilkan Bakteriosin.

Berdasarkan hasil yang diperoleh terdapat tiga isolat pada lokasi I (dekat Hypermart) yaitu dua bakteri Staphylococcus epidermidis dan satu bakteri Bacillus subtilis, dua isolat di lokasi II (depan Matahari) yaitu satu bakteri Stomatococcus dan bakteri Bacillus subtilis, dan empat isolat di lokasi III (dekat XXI) yaitu satu bakteri Staphylococcus epidermidis dan tiga bakteri Bacillus subtilis, hal tersebut 
membuktikan bahwa semakin banyak pengunjung semakin besar kemungkinan didapati lebih banyak bakteri.

Melalui diskusi secara langsung dengan pimpinan pusat Perbelanjaan ini pegangan eskalator di bersihkan sehari sekali pada waktu pagi sebelum pusat perbelanjaan ini di buka. Hal tersebut dapat menjadi alasan mengapa hanya tiga jenis bakteri saja yang di dapatkan.

\section{KESIMPULAN}

Bakteri yang terdapat pada pegangan eskalator di salah satu pusat perbelanjaan di Manado yaitu Staphylococcus epidermidis, Stomatococcus sp., dan Bacillus subtilis.

\section{DAFTAR PUSTAKA}

Aldosary, S.K.A. 2016. Handborne Transmision of Infectious Agents by Escalator Handrails, Shopping Carts, and Automated Teller Machines (ATMs). Science and Technology. 14(1):128-130

Ashgar, S. dan H.M, El-Said. 2012. Pathogenic bacteria associated with different public environmental sites in Mecca City. Open Journal of Medical Microbiology. 2:133-137.

Badan Pusat Statistik. 2010. Sensus Penduduk Provinsi Sulawesi Utara <http://sulut.bps.go.id/linkTabelStatis/ view/id/38> [diakses 8 Oktober 2016]

Cappuccino, JG dan N, Sherman. 1987. Microbiology: A Laboratory Manual. The Benjamin/Cummings Publishing Company, Inc. Clifornia.

Fanourgiakis, P., A, Georgala., M, Vekemans., D, Daneau., C, Heymans., dan M, Aoun. 2003. "Bacteremia due to Stomatococcus mucilaginosus in neutropenic patients in the setting of a cancer institute". Clinical Microbiology and Infection. 9(10):1068-1072.

Gogugu, Z., R.J, Poluan., dan A.M, Malik. 2015. Analisis Daya Tarik "Mantos Mall" Bagi Masyarakat Kota Manado [pdf]. eJournal Unsrat.

Herrmann, E., Mathias., Peters, G. 1995. "Antimicrobial Susceptibilities of Stomatococcus mucilaginosus and of Micrococcus spp.". Antimicrobial
Agents and Chemotherapy. 39 (1): 268-270.

Jawetz, E., J, Melnick dan Adelberg. 2004. Mikrobiologi Kedokteran Edisi 23. EGC. Jakarta

Jawetz, E., dan J, Melnick. 2010. Review of Medical Microbiology 15th edition. Lange Medical Publication : California.

Kamus Online Bahasa Indonesia. 2016. Eskalator.

$<$ http://kamusbahasaindonesia.org/eska lator> [diakses 17 Mei 2016]

Lay, BW. 1994. Analisis Mikroba di Laboratorium. Jakarta: Grafindo. ISBN 979-421-388-8.Hlm.110

Marpaung, P. 2000. Analisis Pembangunan Nilai Sosial Budaya dan Pengaruhnya Terhadap Pembangunan Wilayah di Kecamatan Pangururan Kabupaten Tapanuli Utara (Tesis). Universitas Sumatra Utara

Neo, Lynda Wee Keng dan Tong Kok Wing, 2005. The 4Rs of asian Shopping Centre Management. Jakarta: Gramedia Pustaka Utama

Nurhari. 2009. Mikrobiologi Uji IMVIC. <https://www.scribd.com/doc/2604037 5/mikrobiologi-uji-IMViC-Ogi-Nh> [diakses 19 Juni 2016]

Syah, F. 2007. Perencanaan Eskalator Lantai Satu ke Lantai Dua di Gedung Pusat Perbelanjaan Tanggerang [Skripsi]. Universitas Mercu Buana

Radji, M. 2011. Buku Ajar Mikrobiologi Panduan Mahasiswa Farmasi dan Kedokteran. EGC. Jakarta

Sciffman dan A, Kanuk. 2004. Analisa Marketing Mix, Lingkungan Sosial, Psikologi Terhadap Keputusan Pembelian Online Pakaian Wanita. Jurnal Manajemen Pemasaran Petra. 1(2)

Sompie, D.P.R dan L, Kristanto. 2013. Fasilitas Perbelanjaan dan Rekreasi di Manado. Jurnal eDimensi Arsitektur. 1(2)

Trampuz, A. dan A.F, Widmer. 2004. Hand Hygine: A Frequently Missed Livesaving Opportunity During Patient Care. Mayo Clinic Proceedings.79:109-116

Wattimena. 1991. Farmakodinamik dan Terapi antibiotic. Universitas Gajah Mada. Press, Yogyakarta. 